\title{
CREB5 Gene
}

National Cancer Institute

\section{Source}

National Cancer Institute. CREB5 Gene. NCI Thesaurus. Code C38542.

This gene plays a role in CAMP response element-dependent transcriptional activation. 